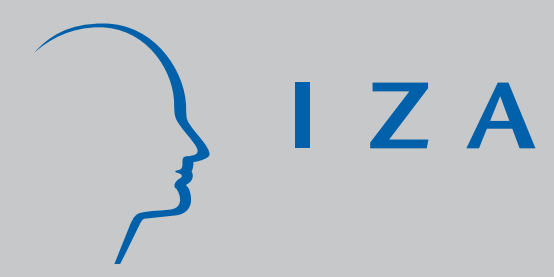

IZA DP No. 2822

On the Dynamics of Ethnic Fractionalization

Nauro F. Campos

Vitaliy S. Kuzeyev

J une 2007 


\title{
On the Dynamics of Ethnic Fractionalization
}

\author{
Nauro F. Campos \\ Brunel University \\ CEPR, WDI and IZA
}

Vitaliy S. Kuzeyev
Ak-Bidai Ltd.

Discussion Paper No. 2822

June 2007

\author{
IZA \\ P.O. Box 7240 \\ 53072 Bonn \\ Germany \\ Phone: +49-228-3894-0 \\ Fax: +49-228-3894-180 \\ E-mail: iza@iza.org
}

\begin{abstract}
Any opinions expressed here are those of the author(s) and not those of the institute. Research disseminated by IZA may include views on policy, but the institute itself takes no institutional policy positions.
\end{abstract}

The Institute for the Study of Labor (IZA) in Bonn is a local and virtual international research center and a place of communication between science, politics and business. IZA is an independent nonprofit company supported by Deutsche Post World Net. The center is associated with the University of Bonn and offers a stimulating research environment through its research networks, research support, and visitors and doctoral programs. IZA engages in (i) original and internationally competitive research in all fields of labor economics, (ii) development of policy concepts, and (iii) dissemination of research results and concepts to the interested public.

IZA Discussion Papers often represent preliminary work and are circulated to encourage discussion. Citation of such a paper should account for its provisional character. A revised version may be available directly from the author. 


\section{ABSTRACT}

\section{On the Dynamics of Ethnic Fractionalization*}

Does fractionalization change over time? If so, are there any substantial implications for economic performance? To answer such questions, we construct a new panel data set with fractionalization measures for 26 former communist countries covering the period from 1989 to 2002. Our fractionalization measures show that transition economies became more ethnically homogenous over such a short period of time, although the same did not happen in terms of linguistic and religious fractionalization. In line with the most recent literature, there seems to be little effect of (exogenous) fractionalization on macroeconomic performance (that is, on per capita GDP growth). However, we find that dynamic ethnic fractionalization is negatively related to growth (although this is still not the case for linguistic and religious fractionalization). These findings are robust to different specifications, polarization measures, instrument sets as well as to a composite index of ethnic-linguistic-religious fractionalization.

JEL Classification: $\quad$ O11, Z12, O55, H1

Keywords: ethnic fractionalization, polarization, growth, transition economies

Corresponding author:

Nauro F. Campos

Department of Economics and Finance

Brunel University

Uxbridge, Middlesex UB8 3PH

United Kingdom

E-mail: Nauro.Campos@brunel.ac.uk

\footnotetext{
* The authors would like to thank Jan Fidrmuc, Julius Horvath, Gabor Kezdi, Branko Milanovic, Jeffrey Nugent, James Robinson, Colin Rowat, Marianne Stewart, and three anonymous referees for valuable comments on previous versions. The responsibility for all remaining errors is entirely ours.
} 


\section{Introduction}

What makes a society human is not the absence of conflict, but the manner in which it administers conflict. A good deal of the history of human societies can be told through the changes in the technology of administering conflict. Social groups formed along ethnic, linguistic, religious, and cultural lines and as their size grew and the costs and complexities of daily interactions increased, more sophisticated ways of managing conflict emerged. Differences are the root of conflict (be them differences of taste, preference, persuasion, understanding, or perspective.) Over time, societies have devised different ways of administering their differences, from tribes to armies to religion to voting (Snyder 2000). Applying a comparative perspective to these issues is valuable (if not essential): more traditional or poorer societies tend to manage conflict in a more immediate and raw way (e.g., through purges or ethnic cleansings), while more industrialized or richer societies are able to manage conflict better in the sense that intraand inter-group physical violence happens less frequently, in a less generalized way and/or in a smaller scale. The hordes, the tribes, the gangs, and the mobs of some societies are the political parties, the lobbying groups, the governments, and the mafias of others.

The literature on the economic consequences of ethnic conflict, civil war, political instability, and fractionalization is now sizeable, while in the early 1990s it was at best incipient. In terms of recent conceptual advances, Esteban and Ray $(1994,1998)$ argue for a distinction between fractionalization and polarization and propose measurement and estimation methods to assess this distinction (see also Nehring and Puppe 2002). In terms of the empirical literature, the economic consequences of diversity (be it ethnic, religious, or linguistic) have been extensively investigated at the country, city, and village levels in developed and developing countries around the globe (notice the exclusion of "over time," more on this below) and in terms of, inter alia, economic growth, income inequality, trade, fiscal deficits, and government consumption (see Alesina and La Ferrara 2005 for an authoritative survey).

Seminal empirical papers are Mauro (1995) and Easterly and Levine (1997), both 
showing that ethno-linguistic fractionalization negatively affects macroeconomic performance.

There has been, however, somewhat limited success in sustaining the evidence for this direct negative effect. For instance, Easterly (2001) shows that the effect of ethnic fractionalization is conditional: it affects growth negatively only in countries with "sufficiently bad" institutions. Bluedorn (2001) and Alesina et al. (2003) argue that the negative impact of diversity on growth is strong mostly in less democratic countries. ${ }^{1}$ Posner (2004) shows that the negative effect is supported only by a restricted polarization index (restricted in that it includes only the "politically relevant" ethnic groups.) Montalvo and Reynal-Querol (2005) demonstrate that while the direct effect of fractionalization on growth is statistically weak, that of ethnic polarization is robust. In sum, the negative first-order effect of ethnic diversity on economic performance is not currently deemed robust as the literature has turned to identifying the main channels (i.e., indirect effects) through which diversity may affect the economy. One main point we make in this paper is that the decision to abandon the possibility of a first-order effect may have been premature. The possibility that diversity changes over time and that it should be treated endogenously does not seem to have been explored empirically (in large part, we gather, due to data demands.)

Alesina and La Ferrara (2005) review this empirical evidence and identify two main directions for future research: to improve the measurement of diversity and to treat diversity as an endogenous variable. ${ }^{2}$ This paper tries to address these two concerns. With respect to measurement, note that most of the literature uses secondary data (e.g., from the CIA Factbook and from Taylor and Hudson's World Handbook of Political and Social Indicators) to construct fractionalization indexes at the national level. In this paper, we put together a data set that

\footnotetext{
${ }^{1}$ Another channel is that ethnic diversity can generate political instability (Campos and Nugent 2002, 2003; Fearon and Laitin 2003). Vanhanen (1999) studies the relationship between ethnic diversity and ethnic conflict.

${ }^{2}$ This body of evidence shares two features: the use of secondary data to measure diversity and the treatment of diversity as an exogenous variable. These two features are related. The secondary data used to measure diversity refers to the early 1960s (Atlas Narodov Mira 1964) and can thus be used mainly as an initial condition (exogenous) variable.
} 
contains primary data, the majority of which from national censuses. ${ }^{3}$ In terms of treating diversity as an endogenous variable, we concentrate on exploiting the genuine time variation shown by our new measures that, to the best of our knowledge, is unique to our data set.

Our study centers on how diversity changes over time for a sample of countries that closely resemble a "natural experiment" (the 26 former centrally planned economies, from 1989 onwards). These are said to resemble a "natural experiment" because until 1989 these countries shared a similar set of economic and political institutions, but have since followed radically different economic and political trajectories (Campos and Coricelli 2002). Our indices strongly confirm the hypothesis that diversity changes over time. They reveal that transition economies have experienced large increases in ethnic (and to a lesser extent in religious and linguistic) diversity between 1989 and 2002. Among the potential reasons for such dramatic changes over a relatively short period of time, we point to the collapse of the Soviet Union (Roeder 1991) and of the Socialist Bloc as a whole, as well as the emergence of new independent countries. In addition, open borders to the West and a worsened domestic economic environment may have caused people to consider looking for better opportunities elsewhere resulting in greater migration and ensuing changes in demographic composition. A choice of religious beliefs, previously absent, as well as decrease in number of Russian schools across these countries, are some of the factors that may have influenced religious and linguistic diversity measures, respectively (Fowkes 2002).

In addition to documenting dramatic changes in fractionalization across countries over time, we use the new measures to revisit the question of the macroeconomic consequences of diversity. We replicate the most recent results from the literature and show that static diversity is indeed not robustly related to economic growth. However, that is not the case when we capture

\footnotetext{
${ }^{3}$ Microcensus data were used when national census data were unavailable. Yet we must qualify this statement by noting that that census questionnaires tend not to contain questions on language nor religion (and this is especially true of the 1989 censuses carried out still under communism). Below, we discuss these issues in greater detail.
} 
empirically how ethnic diversity changes over time and treat it as an endogenous variable. Our panel estimates show that (dynamic) ethnic fractionalization is negatively related to growth. ${ }^{4} \mathrm{We}$ show that this finding is robust to the use of different specifications, polarization measures, instrument sets as well as to a composite index of ethnic-linguistic-religious fractionalization.

It must be noted at the outset that we leave one major suggestion for future work, namely an investigation of the ultimate causes of the variation of diversity over time. Although in what follows we suggest various links between the history of individual countries and our set of potential determinants, on the one hand, and the behavior of our diversity measures over time, on the other, we need to stress that these are just suggestions. We have focused our attention on improving the measurement of diversity and on offering a first glimpse at the possibility that diversity changes over time and how much this recognition would further our understanding of the effects of diversity on economic performance. Although we believe we succeeded in our two main objectives, it would be prudent not to read too much in terms of the ultimate causes of diversity in our econometric estimates, and we thus leave this issue as our main recommendation for future research efforts.

The paper is organized as follows. In the next section we briefly review the literature with special attention to measurement and cross-country econometric estimates with a view to support the notion that the initial results on the negative economic consequences of diversity are currently deemed not robust. We then detail the construction of our data set and of our family of diversity measures. We also discuss various trends we identify in the raw data and argue that dramatic changes in the diversity measures seem to have indeed taken place. The following section contains our two main empirical results: first, we find little evidence of direct or firstorder effects of (exogenous) diversity on economic growth (which is very much in line with the current literature) and, second, although endogenous ethnic diversity is negatively related to

\footnotetext{
${ }^{4} \mathrm{We}$ also replicate the result that linguistic and religious fractionalization measures (now time-variant) are not robustly related to economic growth.
} 
growth (with equally robust results obtaining for polarization measures), that is still not the case regarding linguistic and religious diversity. We then conclude and present some suggestions for future research.

\section{The Effects of Fractionalization: A Review of the Literature}

The index constructed by Soviet researchers in the early 1960s and published in the Atlas Narodov Mira (Bruk and Apenchenko 1964) is omnipresent in the literature. This index of ethnic-linguistic fractionalization (ELF hereafter) is constructed using the shares in total population of all ethno-linguistic groups within each country. Among the reasons for the popularity of this index are that it has an intuitive construction and interpretation, and that it has been included in the influential Taylor and Hudson's World Handbook of Political and Social Indicators since its very first edition. Further, Taylor and Hudson (1972) argue that this source suffers little from ideological bias.

The calculation of this index requires, first, enumeration and precise definition of the ethnic and linguistic categories into which a society is divided. The index is computed as 1 (one) minus the sum of squared group shares. It thus captures the probability that two randomly selected individuals belong to different groups. The index ranges from zero to one, with values close to one indicating a highly fractionalized society and values close to zero indicating a highly homogenous society.

Most cross-country studies use this measure. Mauro (1995) and Easterly and Levine (1997) find that economic growth decreases with ethno-linguistic fractionalization. Easterly and Levine (1997) find that ethno-linguistic fractionalization is detrimental to long-run growth in cross-country regressions. They argue that much of Africa's poor economic performance is related to the high levels of ethnic fractionalization in the continent. The mechanism is that ELF reduces the likelihood of countries adopting what they call "good policies." Their results were broadly confirmed by Alesina et al. (2003). These authors construct a set of ethnic, linguistic, 
and religious fractionalization indices for 190 countries for one point in time (the early 1990s) and find a significant negative relation between ethnic and linguistic fractionalization, on the one hand, and macroeconomic policies and public goods provision, on the other. Note they do not find a significant relationship between religious diversity and growth.

Alesina, Baqir, and Easterly (1999) argue that ethnic diversity lowers growth through a reduction in levels of public good provision. Arcand, Guillaumont, and Guillaumont Jeanneney (2000b) argue that diversity operates directly through the allocation of public and private resources rather than indirectly through policies. The direct adverse effect of ELF on growth is most severe in countries where communications costs are high, the latter often associated with high rates of illiteracy and low population density (Arcand, Guillaumont, and Guillaumont Jeanneney 2000a).

Another channel that has received a great deal of attention is civil war. Elbawadi and Sambanis (2002) find a significant relation between ethnic divisions and the frequency of civil wars. Caselli and Coleman (2002) focus on the relationship between ethnic diversity and natural resources abundance and how it ultimately affects growth negatively. Collier and Hoeffler (1998) investigate the economic causes of civil wars and find a positive relation between ELF and risk of conflict but this relationship is not monotonic: the highest probability of conflict occurs when fractionalization approaches .4. Interestingly, Collier and Hoeffler (2002) find no effect of ethnic polarization on the likelihood of conflict. Collier (2001) shows that the harmful effect of ethnic diversity on growth depends on the political environment: diversity is detrimental to overall economic performance in the context of limited political rights, but is not as damaging in democracies. Fearon and Laitin (2003) argue that the factors that explain which countries have been at risk of civil war are not their ethnic or religious characteristics, but rather things like poverty, political instability, and larger populations. ${ }^{5}$

\footnotetext{
${ }^{5}$ Fearon and Laitin (2003) use, in addition to ELF, two measures of linguistic and ethnic fractionalization constructed from the CIA World Factbook and a measure of linguistic fractionalization.
} 
La Porta et al. (1999) investigate empirically the determinants of the quality of governments in a large cross-section of countries. They assess government performance using measures of government intervention, public sector efficiency, public goods provision, size of government, and political freedom. They find that countries that are poor, closer to the equator, and more ethno-linguistically heterogeneous tend to exhibit inferior government performance. Alesina and Spolaore (2003) use ELF-style measures to explore the relationship between borders, the size of nations, and degree of ethnic and linguistic fractionalization.

Montalvo and Reynal-Querol (2003) analyze the effect of religious diversity on economic growth. They use the Solow growth model from Mankiw, Romer, and Weil (1992) enlarged with religious polarization variables. They find, in contrast to Collier and Hoeffler, that religious polarization is a better measurement of the effect of potential conflict on economic development than the traditional fractionalization index.

Annett (2001) constructs new indexes of ethnic and religious fractionalization for a large cross-section of countries using data from the World Christian Encyclopedia. He studies the relationship between ethno-linguistic-religious fractionalization and both political instability and government consumption. Greater fractionalization is expected to lead to political instability, which in turn leads to higher government consumption aimed at placating political opposition. There is also a feedback mechanism whereby the higher consumption leads to less instability as government consumption reduces the risk of being voted out of office. All these hypotheses find support in his data.

Alesina et al. (2003) update the original ELF index by calculating individual measures of ethnic, linguistic, and religious fractionalization for 190 countries in the 1990s. Their main source is the Encyclopedia Britannica. They argue their measures are more comprehensive than those previously used in the literature as these data, which features the underlying group structure of ethnicities, religions, and languages, allows the computation of alternative measures of heterogeneity (that is, fractionalization as well as polarization). The following results obtain: 
(1) the impact of ELF on growth is negative and robust; (2) ELF is highly correlated with GDP per capita, latitude, and the quality of government so that is difficult to be assertive on causality; and (3) while high ethnic fractionalization is associate with low government quality, the reverse seems true with respect to religious fractionalization.

Posner (2004) argues that most measures of ethnic diversity (including the commonly used Soviet ELF measure) are inappropriate for testing the hypothesis that ethnic diversity affects growth through its effect on macroeconomic policies. ${ }^{6}$ The reason is that those were constructed from enumerations of ethnic groups that include all of the ethnographically distinct groups in a country, irrespective of whether they engage in the political competition whose effects on macroeconomic policymaking are of interest. He presents a new index of ethnic fractionalization based on an accounting of politically relevant ethnic groups in a sample of 42 African countries over time. ${ }^{7}$ He uses this measure (PREG, Politically Relevant Ethnic Groups) to replicate Easterly and Levine's influential article on Africa's "growth tragedy" (1997) and finds that PREG can better account for the policy-mediated effects of ethnic diversity on economic growth in Africa.

A number of works have improved upon the ELF index. Hybrid measures of polarization include Woo's (2003a) composite of income inequality, institutional quality, and ELF. Although societal fractionalization should reflect the extent to which membership in one group (e.g., ethnic) is correlated with that of other groups (e.g., religious and linguistic), the use of aggregate national statistics seems to have prevented measures of fractionalization of capturing this dimension. Woo (2003b) found that social fractionalization has a negative effect on fiscal

\footnotetext{
${ }^{6}$ Fearon (2003) provides a detailed discussion of conceptual and practical problems involved in enumerating "ethnic groups." He combines data from the Encyclopedia Britannica and the CIA Factbook to present a list of 820 ethnic groups in 160 countries that made up at least $1 \%$ of country population in the early 1990s. He also identifies additional problems such as that dissimilar ethno-linguistic groups are frequently aggregated under one umbrella, while some other groups are often omitted altogether.

${ }^{7}$ Posner also calculates a PREG index that changes over time (four decades), however he notes that "the quality of the new index depends fundamentally on the quality of the (necessarily subjective) decisions that were made to consolidate or drop groups from the original Atlas counts" $(2004,855)$. Ultimately, PREG values are the same over the four decades (1960s to 1990s) for all but seven countries.
} 
deficits in countries with weak institutions. This effect is reduced or even suppressed in countries with strong institutions.

Keefer and Knack (2002) use a subjective measure of the intensity of ethnic tensions as well as an index (constructed by Sullivan 1991) that measures the percentage of a country's population belonging to the largest ethnic group. They discuss the various theoretical channels through which social divisions influence growth. They argue that social polarization reduces the security of property rights and, through this channel, reduces growth. The first hypothesis is supported by cross-country evidence indicating that polarization in the form of income inequality, land inequality, and ethnic tensions is inversely related to an index of the security of contractual and property rights. When the security of property rights is accounted for in crosscountry growth regressions, it weakens the relationship between inequality and growth.

In summary, there is a growing literature on the economic effects of fractionalization. The negative first-order (direct) effect of ethnic diversity on economic performance seems to be now downplayed, with the literature turning its attention to identifying the main channels through which fractionalization and polarization may affect the economy (i.e., second-order or indirect effects). One point we make in this paper is that the decision to abandon the possibility of a first-order effect may have been premature. We believe the reason for this is correctly identified by Alesina and La Ferrara (2005): the possibility that diversity changes over time and that it should be treated endogenously does not seem to have been explored empirically in full. There has been substantial effort to improve the measurement of diversity, but that has not so far tried to capture the possibility that diversity can genuinely change over time. That is our task in the next section.

\section{The Measurement of Diversity across Countries and over Time}

The objective of this section is to describe in detail the panel data set we put together to examine the dynamics of fractionalization in the Central European and former Soviet Union countries 
from 1989 t0 2002, that is, over the period covering the entire transition from centrally planned to market economy. Data availability influenced country as well as time coverage. On the former, we measure fractionalization for following 26 transition economies: Albania, Armenia, Azerbaijan, Belarus, Bulgaria, Croatia, Czech Republic, Estonia, Georgia, Hungary, Kazakhstan, Kyrgyz Republic, Latvia, Lithuania, Macedonia, Moldova, Mongolia, Poland, Romania, Russian Federation, Slovakia, Slovenia, Tajikistan, Turkmenistan, Ukraine, and Uzbekistan.

Regarding time coverage, we note that although national censuses are the preferred and most reliable source of fractionalization data, they are conducted once a decade at best, which generates an difficulty in light of our objective of capturing fractionalization dynamics. Further, microcensuses and demographic surveys are conducted at irregular intervals and only in some of the countries in our sample. With this in mind, we decided to first assess what would be the maximum number of time periods for which we could obtain data on the ethnic, linguistic, and religious demographic composition for the 26 transition countries above. ${ }^{8}$ After taking stock of all available data, we find that a balanced panel would be possible for three time periods, namely the early transition period (1989-93), the middle transition period (1994-98), and the late transition period (1999-2002). Consequently, for our sample of 26 transition countries, we construct fractionalization indexes for these three time periods for a grand total of 78 observations. It is also important to bear in mind that we focus on three dimensions of fractionalization (ethnic, linguistic, and religious), so that the data set contains a total of 234 observations on these various aspects of fractionalization (see Appendix A).

In the case of ethnic fractionalization, census data are available for approximately $60 \%$ of the country-period "cells." 9 The fact that for some of these (about 40\%) census data is

\footnotetext{
${ }^{8} \mathrm{~A}$ balanced panel is not necessary but is desirable because it allows each country and time period to carry the same weight in the estimation stage. The data set constructed for this study (including the raw group data) is available from the authors upon request.

${ }^{9}$ The ethnic group status indicator in national censuses is determined by the respondent, in other words, it is not determined on the basis of the official ethnicity in the respondent birth certificate or passport.
} 
nonexistent calls for microcensus and demographic surveys data. The first stage of this process was to collect all available information for each of the three dimensions of fractionalization for the 26 countries and for the three time periods we determine. An exhaustive list of sources was used to check these data. It is worth mentioning that it includes Nasii I Etnosi V Sovremennom Mire (Rosenko 1999, in Russian), David Levinson's Ethnic Groups Worldwide (1998), Natsionalniy Sostav Naseleniya SSSR (Ethnic Composition in The USSR, Finansi I statistika, Moscow, 1991, in Russian), the CIA World Factbook, Encyclopedia Britannica, and Europa World Yearbook as well as a large number of national language publications such as bulletins from Azerbaijan's Department of Conflict and Migration, from the Center for Demography and Ecology of Russian Academy of Science, and the Ethnic Atlas of Uzbekistan (Open Society Institute Assistance Foundation 2002).

Once all available data were collected, for some countries we find more than one estimate for given time period and so a decision rule was needed. If two or more figures for the index of ethnic fractionalization were identical up to the third decimal place, we selected these (and excluded those that diverged). From these, we chose the combination that generated the most balanced distance among the indices over time as well as the largest possible time span within the sample periods. For example, we found estimates of the ethnic composition of the Latvian population for the years 1994, 1995, and 1996 from various different sources, with ethnic fractionalization identical up to the third decimal place. According to this rule, the time series 1989-1994-2000 was preferred to 1989-1996-2000. In addition, if the sources diverged such that their ethnic fractionalization indices were different up to the second decimal place, we choose the one that caused less variability for each country over time. Notice that this decreases source-variability as much as possible. We also believe this "stacks the cards" against us because it explicitly flattens the behavior of diversity over time.

For the computation of the fractionalization indices, we applied the usual formula which captures the probability that two randomly selected individuals belong to different groups: 


$$
F=1-\sum_{i}^{n} s_{i}^{2}
$$

where $\mathrm{s}_{\mathrm{i}}$ is the share of total population belonging to group $i$. The index takes values between zero and one, where $\mathrm{F}$ equals to 1 implies a highly heterogeneous country and $\mathrm{F}$ equals to 0 refers to a perfectly homogeneous country. ${ }^{10}$

One well-known problem when computing ethnic fractionalization indices are the precise definitions of ethnic groups and the fact that these may change over time. ${ }^{11}$ Fearon (2003) notes that Somali clans are often referred to as different "ethnic" groups, yet they are not culturally different in any fundamental aspect. In the same vein, Moldavians and Romanians have virtually the same origin and speak the same language (with some minor differences). A second problem is that these group definitions may change over time for political reasons. Alesina et al. (2003) note that Somalia was often counted as a relatively homogeneous country, that is, until a civil war broke up in 1991. In our sample, there are no significant disputes of these types. One minor exception is that, in some countries, Muslims were considered as one group, while in others Sunni and Shia Muslims were differentiated.

Another well-known shortcoming of this measure of fractionalization is that the same value of the index may correspond to rather different distributions (Fearon 2003). ${ }^{12}$ In our sample, the religious composition of the Latvian population in 1995 comprised one large group ("others including nonreligious" with $62.5 \%$ of the total population), two equal size groups, Roman Catholic and Evangelical Lutheran (with $14.9 \%$ and 14.6\%, respectively) and Russian

\footnotetext{
${ }^{10}$ Note that there is no minimum group size used in the implementation of this formula below, however in what follows we evaluate fixing the number (not the size) of groups across countries over time.

${ }^{11}$ Even Census data on ethnicity, language, and religion is not as reliable as data on, say, age and gender. Ethnicity, language, and religion are very likely to be "endogenous" in a broader sense than that used in this paper: in that of having an ambiguous relationship to economic and physical security. Self-assigned ethnicity may be a "state-of-mind" in the sense that it can change rapidly without any corresponding physical change. Social, natural, and economic events can change the minds of whole communities in terms of how they define themselves creating difficult problems for those studying these changes. For further discussion, see, among others, Fearon and Laitin (2000), Horowitz (2000, especially Chapter 2), Bodenhorn and Ruebeck (2003) and Bertrand and Mullainathan (2004).

${ }^{12}$ Another weakness of the index is its inability to differentiate those groups that are politically strong from the ones that are weak, as strength is not necessarily a function of group's size (Annett 2001; Posner 2004).
} 
Orthodox (8\%), yielding a fractionalization index of 0.5595 . The value of the same index for Macedonia in 1993 is roughly the same: 0.5622 . Yet, Macedonia had one dominating group, Serbian Orthodox (58.94\%), with a second largest being Sunni Muslims (26.09\%) and the smallest one Others (14.98\%). Hence, two countries with different demographic structures in terms of religious preferences have almost identical levels of fractionalization. This is one reason many recent studies favor the concept of polarization over that of fractionalization.

The sensitivity of such indexes to the number of underlying groups made us evaluate two approaches for the computation of fractionalization. In the first, we used all disaggregated data we can ("unrestricted number of groups"), while in the second we restrict the number of groups for each country to be the same over time. This approach has been used in this literature by, among others, Alesina et al. (2003) and Fearon (2003). The average number of ethnic groups in the restricted sample was 5.19, while it was 7.04 in the unrestricted sample. The corresponding figures from Alesina et al. (2003) and Fearon (2003) for Eastern Europe and former Soviet Union countries are 6.48 (27 observations) and 4.55 (31 observations), respectively. The lowest number of groups, we report, including "others," is 3 (in several cases), and the largest is 8 (12 for Mongolia in the unrestricted sample). Table 1 shows that the impact of the differences between restricted and unrestricted indexes is small for our sample. Table 1 also shows that diversity changes over time.

Why does diversity change over time? One general cause is, of course, migration flows. These may be driven by better economic performance and opportunities in the destination country as well as by inferior economic performance and/or civil war and ethnic cleansing in the origin country. In other parts of the world, such process may have taken decades to unfold. However, the rather special circumstances of our sample of transition countries allow for this process to take place in a much shorter period of time. ${ }^{13}$ Firstly, with the collapse of

\footnotetext{
${ }^{13}$ As noted, an investigation of the ultimate causes of the changes in diversity over time is beyond our objectives in this paper. Interesting attempts to link the changes in diversity to individual countries' histories can be found in Tishkov (1997) and Mungiu-Pippidi and Krastev (2004).
} 
communism, workers became free to move to other countries (while under communism, mobility restrictions often referred to the city or province) in search of better economic opportunities. Secondly, the reaction of Russian minorities to the end of the empire was often return migration, causing the share of Russians to fall in every country in our sample, with the exception of Moldova. There are two points to be made in this respect: one is that the mechanisms behind return migration varied across the former Soviet Republics (in the Baltics, for instance, it took the form of incredibly difficult language tests) and, second, that although the Russian minorities tend to occupy visible positions across the Republics, numerically they were very often a minority. Consider the fact that only in six of the countries of our sample, the share of the Russian ethnic group in total population is above $10 \%$ in Period 1 (the early transition period). ${ }^{14} \mathrm{~A}$ third important factor is the eruption of violent conflict, for example, the wars in the Caucasus and former Yugoslavia. Because of the latter, the share of Serbs in Croatia declines from $12.2 \%$ in 1991 to $4.54 \%$ in 2001 . Fourth, Fowkes (2002) argue that many Moravians in the Czech Republic now recognize themselves as Czechs (not as Bohemians), resulting in that the share of the Moravian group falls dramatically from $13.2 \%$ in the 1991 to $3.7 \%$ in the 2001 national census.

In addition to ethnic fractionalization, we compute separate linguistic and religious fractionalization measures, using the same formula and approach as above. A main data source is the Encyclopedia Britannica (1993, 1994, 1999, 2001, and 2002), which report information based on various national data sources. There was little dispersion of the number of groups across time and so we had only one set of indices for each of these two aspects of fractionalization.

The data collection for religious fractionalization comes with one important caveat. Communist countries consistently suppressed the practice of religion for ideological reasons and

\footnotetext{
${ }^{14}$ These are: Belarus (13.22\%), Estonia (30.3\%), Kazakhstan (37.8\%), Kyrgyz Republic (21.5\%), Latvia (33.96\%), and Ukraine $(22.1 \%)$.
} 
therefore did not systematically collect data of this nature. For this reason, we used the earliest estimates that could be obtained for the computation of religious fractionalization indices, usually for 1993.

Table 1 shows how the means of our measures vary over time. ${ }^{15}$ It interesting to note that the dynamics of diversity depends on which of the three aspects we are examining: over such a short period of time, transition countries became much more ethnically homogeneous, yet they also became more religiously diverse, while practically no change is registered with respect to linguistic fractionalization. Focusing on the sample mean for the ethnic fractionalization index, it can be seen it decreases from 0.3726 ( 0.3768 for "unrestricted") to $0.345(0.3538)$ and to 0.3147 (0.3154). In terms of linguistic fractionalization, the mean value of the index declines from 0.3589 to 0.3538 to 0.3501 over the three periods, which is clearly a much smaller change. Therefore, linguistic diversity seems to vary less over time than ethnic diversity, although it at least moves in the same direction. Minorities are often forced by circumstances to use languages other than their own due, for instance, to difficulties to obtain education in their native language. However, especially in the former Soviet Union countries, the Russian language is still widely used. Indeed, in Kazakhstan and in the Kyrgyz Republic, it has been recognized as the second official language.

According to our religious fractionalization index, religious diversity has increased during the transition period: from 0.3862 to 0.4345 to 0.4183 . Investment in religion, through the construction of churches and mosques, provision of literature, organization of special meetings, establishment of religious radio stations and TV channels, can be seen across these countries as after 1989 they were seen as a religious open field. Competition among the various religious groups may be the main explanation for the increased religious fractionalization in the Eastern European and former Soviet Union countries.

\footnotetext{
${ }^{15}$ See Appendix A for the actual diversity indexes, per country and per period.
} 
Table 2 shows the simple correlations between growth and our three measures of fractionalization (also included are other variables used in the regressions below). Ethnic fractionalization is negatively correlated with growth (-0.39), linguistic diversity shows a somewhat smaller negative correlation (-0.35), while religious fractionalization shows an even lower (yet positive) correlation (0.07). It is also interesting to note that both ethnicity and language are positively correlated with black market exchange rate premium $(0.548$ and 0.649 , respectively), which, in turn, is negatively (-0.422) correlated with growth. Finally, noting that language is often used as one criteria to define an ethnic group, the simple correlation for our 78 observations for ethnicity and language is 0.879 ( 0.881 with unrestricted), while that between ethnicity and religion is much smaller: 0.3166 (0.3123 with unrestricted).

In sum, our fractionalization measures reveal substantial changes over a relatively short period of time. While the transition economies became more homogenous in ethnic and linguistic terms, they became more heterogeneous in terms of religion. In quantitative terms, we observe almost no change from 1989 to 2002 in the levels of linguistic fractionalization, while there is a decrease of about $20 \%$ in the levels of ethnic diversity and an increase of about $10 \%$ in the levels of religious fractionalization. Finally, levels of religious fractionalization have been higher throughout (about .40 compared to approximately .35 for ethnic and linguistic diversity).

\section{Empirical Results}

The objective of this section is to revisit the economic effects of diversity. Table 3 shows our estimates for the effects of ethnic fractionalization on the rate of real per capital GDP growth in transition economies between 1989 and 2002. The specifications we use are almost identical to those from Easterly and Levine (1997) and Alesina et al. (2003), with two main differences. One is that we add a dummy variable for CIS membership is added (which takes the value of 1 for all former Soviet Union countries but the Baltics, and zero otherwise) and the other is that we use a war dummy variable as a proxy for political instability for our sample of transition economies 
(instead of assassinations as the latter is not available). Appendix B contains information on data sources and definitions. Another difference, of course, is that here ethnic diversity varies over time. The first column shows that ethnic fractionalization significantly and negatively affects the growth of real per capita GDP. ${ }^{16}$ Based on the literature reviewed above, we should expect that, after controlling for other variables, the direct effect of ethnic fractionalization would vanish. It is therefore not surprising to observe that ethnic fractionalization loses its statistical significance once we control for initial income, schooling, and war. ${ }^{17}$ In columns (4) and (5) the coefficient on ethnic fractionalization increases in size and the fact that its standard error does not change much implies it regains statistical significance. The set of conditioning variables carry the expected signs with the coefficients on the CIS dummy, war, initial income, and human capital also found to be statistically significant. However, the main result is that the effect of ethnic diversity is clearly not robust to changes in the set of conditioning variables and therefore we are able to replicate, with our data, one of the main results from the literature.

In terms of the substantive (as opposed to statistical) significance of the effect of ethnic diversity on growth, Alesina and La Ferrara note that "the estimates (...) suggest that, ceteris paribus, going from perfect homogeneity to maximum heterogeneity (i.e., increasing $E L F$ from 0 to 1$)$ would reduce a country's growth rate by 2 percentage points per year" $(2005,772)$. Interestingly, this is very much the magnitude estimated by Posner (2004), using a similar specification but a different sample of countries (that is, only African nations). From the last column in Table 3, we learn that these effects are larger for our sample and indicate a corresponding reduction of 9 percentage points. This seems to reflect both the larger changes in ethnic diversity and the more severe GDP contractions these economies experienced during the transition period. Yet, recall that the coefficient on diversity is often not statistically significant.

\footnotetext{
${ }^{16}$ Note that Granger-causality tests do not support the notion that causality (in this sense) run from economic growth to ethnic diversity.

${ }^{17}$ Our conclusions are unaffected if initial income only enters linearly.
} 
It is important to note that our research strategy is to, first, follow as closely as possible existing related and representative specifications (such as Easterly and Levine 1997) and, second, to modify these specifications by means of treating diversity as an endogenous variable (which is of course easier to do once we have constructed diversity measures at various points in time). Our expectation is that by doing so we may be able to reestablish the robust negative impact of diversity on per capita GDP growth. ${ }^{18}$

Table 4 follows the same pattern of Table 3, but examining the relationship between linguistic fractionalization and economic growth. As it can be seen, the results show that linguistic fractionalization have a significant impact on growth only in the bivariate regression (in column 1). Yet, we can not replicate this result for any of the other specifications. Notice also that the pattern of signs and statistical significance we observe in the set of conditioning variables for the case of ethnic broadly remains in the case of linguistic diversity. ${ }^{19}$

Our results for religious fractionalization are somewhat different. Table 5 shows that although the unconditional effect of religious fractionalization on economic growth carries the expected negative sign, it is not statistically significant from zero (column 1). Interestingly, the conditional effect of religious fractionalization on growth is actually positive and statistically significant (in columns 2 to 5). Note that this has been found before in larger samples: for instance, the results from Alesina et al. $(2003,170)$ on religious fractionalization, although never statistically significant, show that the coefficient on religious diversity is negative for two of the four specifications reported, while it is positive in the other two. Finally, notice that the pattern we observe in the set of conditioning variables for the cases of ethnic and of linguistic diversity

\footnotetext{
${ }^{18}$ We recognize that more complex relationships may be at work. In particular, ethnic diversity as a source of conflict is one of the main determinants of the occurrence of war (Collier and Hoeffler 2001, 2002). Our understanding is that these two literatures (the one on the macroeconomic effects of diversity and the one on diversity as a potential cause of conflict) have not yet converged and, again, we leave this as one suggestion for future research.

${ }^{19}$ In Appendix C, we show that similar results obtain for a polarization index instead.
} 
remains, with the only exception of the coefficient on war (now statistically insignificant). ${ }^{20}$

In sum, our findings for ethnic fractionalization are in line with most of the recent literature in that these estimates show that the direct effect of fractionalization on economic performance is weak. Similar conclusions can be reached with respect to linguistic and religious diversity. As noted, something the literature has not yet explored is that diversity may change over time and may be endogenous (see, e.g., Alesina and La Ferrara 2005). We now turn to our set of econometric results that try to take these concerns into account.

We proceed by reestimating all the specifications from Tables 3 to 5 using Three Stages Least Squares (3SLS) instead. In addition to its appropriateness in the presence of error correlation across equations, 3SLS compares more naturally with the SUR results presented above and it is also used often in the growth in transition literature (Falcetti, Lysenko, and Sanfey 2006). One important issue is the specification of the "diversity equation" as there has been no effort (to the best of our knowledge) to try to explain empirically the evolution of diversity over time across countries. We therefore resort to a somewhat ad hoc approach as we choose the broadest set of explanatory variables, trying to capture social conditions, political liberalization and economic liberalization. ${ }^{21}$ In order to obtain the best possible predicted value of ethnic diversity, we exclude the most statistically insignificant variable one-by-one in such a way that the adjusted $\mathrm{R}^{2}$ of the "diversity equation" increases after the exclusion. Once it stops increasing, we exclude the second most statistically insignificant variable, and so on and so

\footnotetext{
${ }^{20}$ Using principal components, we also calculate an index of ethnic-linguistic-religious fractionalization. We repeat all the regressions above but using this composite index as a measure of diversity instead. The results are qualitatively similar to those for linguistic fractionalization. These are available upon request.

${ }^{21}$ Once again stressing that our objective is not to provide an explanation for changes in diversity over time (it is instead to recognize that these changes actually take place and assess its impact on economic performance), we note that the intuition behind this extended set of variables is that they represent three potentially important groups of reasons for diversity to change (over time and across countries.) Under social conditions, we think population size, illiteracy, and infant mortality should be associated with ethnic diversity as well as with its change over time, while under political liberalization, we expect civil liberties, political rights, and corruption to be associated with ethnic diversity (for example, we expect to find less restrictions to migration in countries with more entrenched civil liberties and political rights). Although we believe economic liberalization should play a role, the results suggest that the first two groups are actually more important for our sample of transition economies.
} 
forth. Accordingly, we start out with a regression of ethnic fractionalization as endogenous variable with the whole set of variables on the right-hand side, ${ }^{22}$ which generates an Adjusted $\mathrm{R}^{2}$ of 0.45 . From this extended set and using the rule above, we exclude civil liberties, trade and foreign exchange reform indexes, external liberalization index, and small-scale privatization. Ultimately, we settle on a specification for ethnic diversity with an Adjusted $R^{2}$ of 0.486 with the following explanatory variables: infant mortality and bank sector reform (both significant at 10\%), infrastructure, large-scale privatization, price liberalization (all significant at 5\%), illiteracy, latitude, $\log$ of population, and corruption (all significant at $1 \%$ level). ${ }^{23}$

Table 6 shows that the coefficient on "endogenous" ethnic fractionalization is statistically significant throughout at the $10 \%$ level. ${ }^{24}$ This is, of course, in contrast to the results presented in Table 3. As it can be seen, the coefficient on ethnic fractionalization is now statistically significant, irrespective of the set of additional controls we choose to use. They also carry the expected negative sign. The magnitude of the effect of ethnic diversity on growth increases substantially: we find that, ceteris paribus, going from perfect homogeneity to maximum heterogeneity (i.e., increasing ELF from 0 to 1 ) would reduce a country's growth rate by more 10 percentage points per year. Although this figure may seem larger than expected, we think it is credible in light of the very large changes in ethnic diversity and the extremely severe GDP contractions these economies experienced during the transition period. For other groups of developing countries, our expectation is that the effect should be smaller over such a short period of time or that a much longer time period would be required to obtain an effect of

\footnotetext{
${ }^{22}$ See Appendix B, these are civil liberties, competition, democracy, external liberalization, illiteracy, internal liberalization, infant mortality, latitude, population, large-scale privatization, political rights, price liberalization, small-scale privatization, trade and foreign exchange, corruption, infrastructure, financial and GDP per capita level.

${ }^{23}$ Using the Transparency International measure, we find that more corrupt countries tend to be more ethnically and linguistically diverse. Future research will do well in investigating this relationship in detail, in particular, the potential role of nonlinearities and reverse causality.

${ }^{24}$ Some readers may insist in the use of the more standard 5\% "cut-off" for declaring a relationship statistically significant. With this in mind, we estimate a more parsimonious specification corresponding to the Solow growth model (with investment, human capital and population growth as explanatory variables.) Our conclusions are not affected and, indeed, the coefficient on (endogenous not exogenous) ethnic diversity is significant at the 5\% level. These results are available from the authors upon request.
} 
comparable magnitude.

For linguistic fractionalization, we repeat the procedure described above to select a set of predictors for the level of ethnic diversity. Again, we have no knowledge of previous efforts that could provide us with guidance in this respect. We thus start again with the same broad set of explanatory variables (Appendix B). We exclude the most statistically insignificant variables one by one in such a way that the adjusted $\mathrm{R}^{2}$ of the regression increases after the exclusion. Once it stops increasing, we exclude the second most statistically insignificant variables, and so on. In this light, we exclude civil liberties, internal liberalization, and small-scale privatization, and obtain an adjusted $\mathrm{R}^{2}$ of 0.576 with competition, external liberalization, illiteracy, and largescale privatization (all significant at the $10 \%$ significance level), infant mortality and infrastructure (significant at 5\%) and latitude, population, and corruption, significant at the $1 \%$ level. Our results are in Table 7: they do not support the hypothesis that endogenous linguistic fractionalization adversely affects economic growth. As noted, the changes we observe in linguistic are small vis-à-vis those in ethnic fractionalization. Arguably, this is because of inertia of educational and cultural institutions that did not change in the transition economies in this period and thus it may be easier or necessary for individuals to still speak various languages.

Table 8 reports our results for religious diversity we obtain by repeating the procedure above. Once again, we start with a broad set encompassing social conditions, political liberalization, and economic liberalization. Applying our rule we are only able to exclude the three variables (infrastructure, financial and GDP per capita level) and we obtain the smallest Adjusted $\mathrm{R}^{2}$ of all three cases: 0.32 . Further, the results of this exercise are not helpful in clarifying the potential role of religious fractionalization (see Table 5 above). The coefficients on diversity behave erratically, generating almost all four possible combinations of sign and statistical significance in five chances.

In summary, our results strongly suggest that the three different dimensions of fractionalization we consider here show very different effects in terms of real per capita GDP 
growth. The more robust set of results refers to ethnic fractionalization: we replicate the findings from the most recent literature in that exogenous diversity does not play a strong role in terms of economic growth, but we show that endogenizing diversity and taking full advantage of its intertemporal variation pays off as the resulting effects turn out to exhibit the expected signs and are statistically significant across the board. It is a very different situation for religious and linguistic fractionalization: their coefficients are seldom significant and almost never carry the negative signs one would expect. ${ }^{25}$

\section{Conclusions}

This is one of the first papers to use census data to measure ethnic diversity over time and across countries and assess its impact on economic performance. Another contribution of this paper is that it provides measures of linguistic and religious diversity that change over time across a complete set of transition countries. We show that this improvement in the measurement of diversity pays off: in line with the most recent literature, we find little effect of (exogenous) diversity on per capita GDP growth. On the other hand, we find that dynamic ethnic diversity is negatively related to growth (while that is still not the case regarding linguistic and religious diversity). Moreover, we show that these findings are robust to the use of different estimators, specifications, polarization measures, instrument sets as well as to an index of ethnic-linguisticreligious fractionalization.

We leave two further suggestions for future research. ${ }^{26}$ The first is to investigate whether our basic result on the importance of endogenous ethnic diversity (somewhat in detriment of linguistic and religious fractionalization) holds as well for other samples of developed and developing countries. Data requirements make this an expensive and time-consuming proposition. Yet Posner (2004) shows that is feasible to measure diversity over time for the most

\footnotetext{
${ }^{25}$ Appendix $\mathrm{C}$ shows that these results hold for polarization (instead of fractionalization) measures.

${ }^{26}$ From the outset, we pointed out that it is imperative to try to provide a deeper understanding of the reasons for why diversity changes over time.
} 
data deprived region, namely, Sub-Saharan Africa. The second suggestion for future research is to go further in trying to integrate the two so far separate literatures on diversity as a source of conflict (Collier and Hoeffler 2001, 2002) and that revisited here, on the macroeconomic effects of diversity. This will of course require further conceptual work and theoretical modeling but in light of the results above this is clearly an important task. The results presented in this paper also indicate that in pursuing this latter suggestion, great care should be exercised in distilling the potentially divergent effects of ethnic, linguistic and religious diversity on nonviolent and violent conflict as well as on various dimensions of economic well-being. 


\section{References}

Alesina, Alberto, Baqir, Reza, and William Easterly. 1999."Public Goods and Ethnic Divisions.” Quarterly Journal of Economics CXIV (4): 1243-84.

Alesina, Alberto, Arnaud Devleeschauwer, William Easterly, Sergio Kurlat, and Romain Wacziarg. 2003. "Fractionalization.” Journal of Economic Growth 8 (2): 155-94.

Alesina, Alberto, and Eliana La Ferrara. 2005. "Ethnic Diversity and Economic Performance," Journal of Economic Literature XLIII (3): 762-800.

Alesina, Alberto, and Enrico Spolaore. 2003. The Size of Nations. Cambridge: MIT Press.

Annett, Anthony. 2001. "Social Fractionalization, Political Instability, and the Size of Government.” IMF Staff Papers 48 (3): 561-92.

Arcand, Jean-Louis, Patrick Guillaumont, and Sylviane Guillaumont Jeanneney. 2000a. "Ethnicity Communication and Growth." CSAE Working Paper 2000-20. Oxford: University of Oxford.

Arcand, Jean-Louis, Patrick Guillaumont, and Sylviane Guillaumont Jeanneney. 2000b. "How to Make a Tragedy: On the Alleged Effect of Ethnicity on Growth." Journal of International Development 12 (7): 925-38.

Bertrand, Marianne, and Sendhil Mullainathan. 2004. "Are Emily and Greg More Employable Than Lakisha and Jamal? A Field Experiment on Labor Market Discrimination." American Economic Review 94 (4): 991-1013.

Bodenhorn, Howard, and Christopher Ruebeck. 2003. "The Economics of Identity and The Endogeneity of Race.” NBER Working Paper 9962.

Bluedorn, John. 2001. “Can Democracy Help? Growth and Ethnic Divisions.” Economics Letters 70 (1): 121-26.

Bruk, Solomon, and V. S. Apenchenko, eds. 1964. Atlas Narodov Mira. Moscow: Glavnoe upravlenie geodezii i kartografii gosudarstvennogo geologicheskogo komiteta SSSR and Institut etnografii im. H. H. Miklukho-Maklaia, Akademiia nauk SSSR.

Campos, Nauro, and Fabrizio Coricelli. 2002. "Growth in Transition: What We Know, What We Don't, and What We Should." Journal of Economic Literature XL (3): 793-836.

Campos, Nauro, and Jeffrey Nugent. 2002. "Who is Afraid of Political Instability?" Journal of Development Economics 67 (1): 157-72.

Campos, Nauro, and Jeffrey Nugent. 2003. "Aggregate Investment and Political Instability: An Econometric Investigation.” Economica 70 (3): 533-49.

Caselli, Francesco, and Wilbur Coleman. 2002. "On the Theory of Ethnic Conflict." LSE, mimeo.

CIA. 1996. Handbook of Nations 1996, $16^{\text {th }}$ ed. Central Intelligence Agency, Washington. 
CIA. Various years. The World Fact Book. Central Intelligence Agency, Washington.

Collier, Paul. 2001. "Ethnic Diversity: An Economic Analysis.” Economic Policy 32: 127-66.

Collier, Paul, and Anke Hoeffler. 1998. "On Economic Causes of Civil War.” Oxford Economic Papers 50 (4): 563-73.

Collier, Paul, and Anke Hoeffler. 2002. "Greed and Grievance in Civil War." CSAE WPS 2002-01. Oxford: University of Oxford.

Easterly, William. 2001. “Can Institutions Resolve Ethnic Conflict?” Economic Development and Cultural Change 49 (4): 687-706.

Easterly, William, and Ross Levine. 1997. "Africa's Growth Tragedy: Policies and Ethnic Divisions.” Quarterly Journal of Economics CXII (4): 1203-50.

Elbadawi, Ibrahim, and Nicholas Sambanis. 2002. "How Much War Will We See? Explaining the Prevalence of Civil War." Journal of Conflict Resolution 46 (3): 307-34.

Encyclopedia Britannica (various years). Encyclopedia Britannica, Inc.

Esteban, Joan, and Debraj Ray. 1994. "On the Measurement of Polarization.” Econometrica 62 (4): 819-51.

Esteban, Joan, and Debraj Ray. 1999. "Conflict and Distribution." Journal of Economic Theory 87 (2): 379-415.

Europa World Year Book. 1996. London: Europa Publications Ltd.

Falcetti, Elisabetta, Tatiana Lysenko, and Peter Sanfey. 2006."Reforms and Growth in Transition: Re-examining the Evidence." Journal of Comparative Economics 34 (3): 42145.

Fearon, James. 2003. "Ethnic and Cultural Diversity by Country." Journal of Economic Growth 8 (2): 195-222.

Fearon, James, and David Laitin. 2000. "Violence and the Social Construction of Ethnic Identity." International Organization 54 (4): 845-77.

Fearon, James, and David Laitin, 2003, "Ethnicity, Insurgency, and Civil War", American Political Science Review 97 (1): 75-90

Fowkes, Ben. 2002. Ethnicity and Ethnic Conflict in the Post-Communist World, Basingstoke: Palgrave.

Finansi I Statistika (Soviet Ministry of Science). 1991. Natsionalniy sostav naseleniya SSSR (Ethnic composition in USSR), Moscow.

Horowitz, Donald. 2000. Ethnic Groups in Conflict. $2^{\text {nd }}$ ed. Berkeley and Los Angeles: California University Press. 
Keefer, Philip, and Stephen Knack. 2002. "Polarization, Politics, and Property Rights." Public Choice 111 (1-2): 127-54.

La Porta, Rafael, Florencio Lopez-de-Silanes, Andrei Shleifer, and Robert Vishny. 1999. "The Quality of Government.” Journal of Law, Economics and Organization 15 (1): 222-27.

Levinson, David. 1998. Ethnic Groups Worldwide. Phoenix: Oryx Press.

Mankiw, Gregory, David Romer, and David Weil. 1992. "A Contribution to the Empirics of Economic Growth.” Quarterly Journal of Economics 107 (2): 407-37.

Mauro, Paolo. 1995. "Corruption and Growth.” Quarterly Journal of Economics 110 (3): 681712.

Montalvo, Jose, and Martha Reynal-Querol. 2003. "Religious Polarization and Economic Development." Economics Letters 80 (2): 201-10.

Montalvo, Jose, and Martha Reynal-Querol. 2005. "Ethnic Diversity and Development." Journal of Development Economics 76 (2): 293-323.

Mungiu-Pippidi, Alina, and Ivan Krastev. 2004. Nationalism after Communism, Budapest: CEU Press.

Nehring, Klaus, and Clemens Puppe. 2002. “A Theory of Diversity.” Econometrica 70 (3): 1155-98.

Open Society Institute Assistance Foundation. 2002. Ethnic Atlas of Uzbekistan. Uzbekistan.

Posner, Daniel. 2004. "Measuring Ethnic Fractionalization in Africa." American Journal of Political Science 48 (4): 849-63.

Roeder, Philip. 1991. "Soviet Federalism and Ethnic Mobilization.” World Politics 43 (2): 196232.

Russian Demographic Book of the Year. 1998. Moscow.

Rosenko, M. (ed.). 1999. Nasii i etnosi v sovremennom mire (Nations and ethnicity in today's world), Reference-Dictionary, S-Petersburg.

Snyder, Jack. 2000. From Voting to Violence: Democratization and Nationalist Conflict. New York: Norton.

Sullivan, Michael. 1992. Measuring Global Values, New York: Greenwood.

Taylor, Charles, and Michael Hudson. 1972. World Handbook of Political and Social Indicators. New Haven: Yale University Press.

Tishkov, Valery. 1997. Ethnicity, Nationalism and Conflict In and After the Soviet Union. London: Sage.

Vanhanen, Tatu. 1999. "Domestic Ethnic Conflict and Ethnic Nepotism: A Comparative Analysis." Journal of Peace Research 36 (1): 55-73. 
Woo, Jaejoon. 2003a. "Social Polarization, Industrialization, and Fiscal Instability: Theory and Evidence.” Journal of Development Economics 72 (1): 223-52.

Woo, Jaejoon. 2003b. "Economic, Political, and Institutional Determinants of Public Deficits." Journal of Public Economics 87 (3): 387-426. 
Table 1.

Descriptive statistics

\begin{tabular}{|c|c|c|c|}
\hline & Sample mean & Max value & Min. value \\
\hline Ethnicity restricted (78) & 0.3441 & 0.6871 & 0.0139 \\
\hline $\begin{array}{l}\text { 1-st period (26) } \\
\end{array}$ & 0.3726 & 0.6871 & 0.0257 \\
\hline 2-nd period (26) & 0.3450 & 0.6659 & 0.0471 \\
\hline 3-rd period (26) & 0.3147 & 0.6180 & 0.0139 \\
\hline Ethnicity unrestricted (78) & 0.3450 & 0.6869 & 0.0139 \\
\hline \begin{tabular}{|c|}
1 -st period (26) \\
\end{tabular} & 0.3768 & 0.6869 & 0.0257 \\
\hline 2-nd period (26) & 0.3429 & 0.6659 & 0.0471 \\
\hline 3-rd period (26) & 0.3154 & 0.6180 & 0.0139 \\
\hline Linguistic (78) & 0.3543 & 0.6601 & 0.0294 \\
\hline 1-st period (26) & 0.3589 & 0.6338 & 0.0398 \\
\hline 2-nd period (26) & 0.3538 & 0.6598 & 0.0601 \\
\hline 3-rd period (26) & 0.3501 & 0.6698 & 0.0297 \\
\hline Religion (78) & 0.4129 & 0.6947 & 0.0415 \\
\hline 1-st period (26) & 0.3862 & 0.6594 & 0.0694 \\
\hline 2-nd period (26) & 0.4345 & 0.6592 & 0.0792 \\
\hline \begin{tabular}{|c|}
$3-r d$ period (26) \\
\end{tabular} & 0.4183 & 0.6947 & 0.0415 \\
\hline Fearon (2003)'s ethnic (26), (restricted) & 0.3696 & 0.6790 & 0.0470 \\
\hline Fearon (2003)'s ethnic (160), (unrestricted) & 0.4800 & 0.9530 & 0.0020 \\
\hline Fearon (2003)'s culture (26), (restricted) & 0.3002 & 0.6240 & 0.0410 \\
\hline Fearon (2003)'s culture (160), (unrestricted) & 0.3100 & 0.7330 & 0.0000 \\
\hline $\begin{array}{l}\text { Alesina et al. (2003)'s ethnicity (26), } \\
\text { (restricted) }\end{array}$ & 0.3723 & 0.6752 & 0.1183 \\
\hline $\begin{array}{l}\text { Alesina et al. (2003)'s ethnicity (180), } \\
\text { (unrestricted) }\end{array}$ & 0.4350 & 0.9302 & 0.0000 \\
\hline \multicolumn{4}{|c|}{$\begin{array}{l}\text { Source: Authors' calculations. } \\
\text { Note: Number of observations is in parenthesis. "Restricted" means based on the same } \\
\text { number of (ethnic) groups per country over time. See Appendix A for the values of the } \\
\text { fractionalization indices per country over time. 1st period refers to 1989-1993, 2nd period } \\
\text { refers 1994-1998 and 3rd period refers to 1999-2002. See text for further details. }\end{array}$} \\
\hline
\end{tabular}


Table 2.

Correlation matrix

\begin{tabular}{|l|c|c|c|c|c|c|c|c|c|c|}
\hline & growth & ethnicity & linguistic & religion & $\begin{array}{c}\text { log } \\
\text { income }\end{array}$ & BMP & war & school & phone & $\begin{array}{c}\text { log } \\
\text { M2/GDP }\end{array}$ \\
\hline ethnicity & $-0,393$ & & & & & & & & & \\
\hline linguistic & $-0,351$ & 0,879 & & & & & & & & \\
\hline Religion & 0,072 & 0,317 & 0,181 & & & & & & & \\
\hline log int income & $-0,242$ & $-0,094$ & $-0,225$ & 0,199 & & & & & & \\
\hline BlackMP & $-0,422$ & 0,548 & 0,649 & $-0,034$ & $-0,230$ & & & & & \\
\hline War & $-0,285$ & 0,085 & $-0,030$ & $-0,058$ & $-0,136$ & 0,007 & & & & \\
\hline School & 0,097 & $-0,291$ & $-0,498$ & 0,159 & 0,717 & $-0,494$ & $-0,065$ & & & \\
\hline Phone & 0,025 & $-0,153$ & $-0,261$ & 0,223 & 0,666 & $-0,217$ & $-0,132$ & 0,725 & & \\
\hline log M2/GDP & 0,086 & $-0,246$ & $-0,363$ & 0,086 & 0,395 & $-0,367$ & 0,240 & 0,563 & 0,335 & \\
\hline fisc surpl/GDP & $-0,001$ & $-0,042$ & 0,047 & $-0,185$ & 0,213 & $-0,386$ & $-0,353$ & 0,083 & 0,268 & $-0,177$ \\
\hline
\end{tabular}


Table 3.

Ethnic Fractionalization and Economic Growth

SUR (seemingly unrelated regression) estimates

(Dependent variable is growth of per capita GDP)

\begin{tabular}{|c|c|c|c|c|c|}
\hline & (1) & (2) & (3) & (4) & (5) \\
\hline Ethnic fractionalization & $\begin{array}{c}-0.15 * * * \\
(0.04)\end{array}$ & $\begin{array}{c}-0.06 \\
(0.0458)\end{array}$ & $\begin{array}{c}-0.077 \\
(0.0486)\end{array}$ & $\begin{array}{l}-0.09 * \\
(0.052)\end{array}$ & $\begin{array}{l}-0.093 * \\
(0.052)\end{array}$ \\
\hline Dummy for the CIS & & $\begin{array}{c}-0.049 * * * \\
(0.017)\end{array}$ & $\begin{array}{c}-0.042 * * \\
(0.018)\end{array}$ & $\begin{array}{c}-0.052 * * \\
(0.025)\end{array}$ & $\begin{array}{l}-0.040 \\
(0.027)\end{array}$ \\
\hline Log of initial income & & $\begin{array}{c}-0.606^{* * * *} \\
(0.12)\end{array}$ & $\begin{array}{c}-0.610 * * * \\
(0.12)\end{array}$ & $\begin{array}{c}-0.593 * * * \\
(0.13)\end{array}$ & $\begin{array}{c}-0.614 * * * \\
(0.13)\end{array}$ \\
\hline $\begin{array}{l}\text { Log of initial income } \\
\text { squared }\end{array}$ & & $\begin{array}{c}0.03 * * * \\
(0.007)\end{array}$ & $\begin{array}{c}0.031 * * * \\
(0.007)\end{array}$ & $\begin{array}{c}0.03 * * * \\
(0.007)\end{array}$ & $\begin{array}{c}0.030 * * * \\
(0.007)\end{array}$ \\
\hline Schooling & & $\begin{array}{l}0.002 * * * \\
(0.0006)\end{array}$ & $\begin{array}{l}0.003 * * * \\
(0.0006)\end{array}$ & $\begin{array}{l}0.003 * * * \\
(0.0007)\end{array}$ & $\begin{array}{l}0.002 * * * \\
(0.0008)\end{array}$ \\
\hline War & & & $\begin{array}{l}-0.045^{*} \\
(0.027)\end{array}$ & $\begin{array}{l}-0.053^{*} \\
(0.029)\end{array}$ & $\begin{array}{l}-0.054^{*} \\
(0.029)\end{array}$ \\
\hline Financial depth & & & & $\begin{array}{l}-0.001 \\
(0.015)\end{array}$ & $\begin{array}{l}-0.003 \\
(0.014)\end{array}$ \\
\hline Black market premium & & & & $\begin{array}{l}0.001 \\
(0.01)\end{array}$ & $\begin{array}{l}0.001 \\
(0.01)\end{array}$ \\
\hline Fiscal surplus/GDP & & & & $\begin{array}{c}-0.002 \\
(0.0018)\end{array}$ & $\begin{array}{c}-0.001 \\
(0.0018)\end{array}$ \\
\hline Phones per capita & & & & & $\begin{array}{c}0.14 \\
(0.14)\end{array}$ \\
\hline Time period dummies? & Yes & Yes & Yes & Yes & Yes \\
\hline $\mathrm{R}^{2}($ Overall $)$ & 0.15 & 0.19 & 0.19 & 0.21 & 0.20 \\
\hline $\mathrm{N}$ & $26 ; 26 ; 26$ & $26 ; 26 ; 26$ & $26 ; 26 ; 26$ & $26 ; 26 ; 26$ & $26 ; 26 ; 26$ \\
\hline
\end{tabular}

Note: Standard deviations are in parentheses; * significant at $10 \%, * *$ significant at $5 \%, * * *$ significant at $1 \%$ 
Table 4.

Linguistic Fractionalization and Economic Growth

SUR (seemingly unrelated regression) estimates

(Dependent variable is growth of per capita GDP)

\begin{tabular}{|l|c|c|c|c|c|}
\hline & $(1)$ & $(2)$ & $(3)$ & $(4)$ & $(5)$ \\
\hline Linguistic fractionalization & $-0.12^{* * *}$ & -0.04 & -0.06 & -0.06 & -0.07 \\
& $(0.033)$ & $(0.043)$ & $(0.047)$ & $(0.053)$ & $(0.052)$ \\
\hline Dummy for the CIS & & $-0.05^{* * *}$ & $-0.04 * *$ & $-0.05 * *$ & -0.04 \\
& & $(0.016)$ & $(0.018)$ & $(0.024)$ & $(0.027)$ \\
\hline Log of initial income & & $-0.61^{* * *}$ & $-0.62^{* * *}$ & $-0.6^{* * *}$ & $-0.62^{* * *}$ \\
& & $(0.12)$ & $(0.12)$ & $(0.13)$ & $(0.13)$ \\
\hline Log of initial income squared & & $0.03^{* * *}$ & $0.03^{* * *}$ & $0.03^{* * *}$ & $0.03^{* * *}$ \\
& & $(0.007)$ & $(0.007)$ & $(0.007)$ & $(0.007)$ \\
\hline Schooling & & $0.002^{* * *}$ & $0.002^{* * *}$ & $0.002^{* * *}$ & $0.002^{* *}$ \\
& & $(0.0006)$ & $(0.0006)$ & $(0.0007)$ & $(0.0008)$ \\
\hline War & & & $-0.04 *$ & $-0.05^{*}$ & $-0.05^{*}$ \\
& & & $(0.028)$ & $(0.03)$ & $(0.03)$ \\
\hline Financial depth & & & & 0.001 & 0.0003 \\
& & & & $(0.015)$ & $(0.015)$ \\
\hline Black market premium & & & & 0.001 & 0.001 \\
& & & & $-0.01)$ & $(0.01)$ \\
\hline Fiscal surplus/GDP & & & & $(0.0019)$ & $(0.0018)$ \\
\hline Phones per capita & & & & 0.14 \\
& & & & & $(0.14)$ \\
\hline Time period dummies? & Yes & Yes & Yes & Yes & Yes \\
\hline $\mathrm{R}^{2}$ (Overall) & 0.13 & 0.19 & 0.17 & 0.15 & 0.17 \\
\hline $\mathrm{N}$ & $26 ; 26 ; 26$ & $26 ; 26 ; 26$ & $26 ; 26 ; 26$ & $26 ; 26 ; 26$ & $26 ; 26 ; 26$ \\
\hline
\end{tabular}

Note: Standard deviations are in parentheses; * significant at $10 \%$, ** significant at $5 \%, * * *$ significant at $1 \%$ 
Table 5.

Religious Fractionalization and Economic Growth

SUR (seemingly unrelated regression) estimates

(Dependent variable is growth of per capita GDP)

\begin{tabular}{|c|c|c|c|c|c|}
\hline & (1) & (2) & (3) & (4) & (5) \\
\hline Religious fractionalization & $\begin{array}{l}-0.015 \\
(0.04) \\
\end{array}$ & $\begin{array}{l}0.1 * * * \\
(0.037)\end{array}$ & $\begin{array}{l}0.1 * * \\
(0.04)\end{array}$ & $\begin{array}{l}0.09 * * \\
(0.043)\end{array}$ & $\begin{array}{c}0.08^{*} \\
(0.045) \\
\end{array}$ \\
\hline Dummy for the CIS & & $\begin{array}{c}-0.061 * * * \\
(0.014)\end{array}$ & $\begin{array}{c}-0.056 * * * \\
(0.016)\end{array}$ & $\begin{array}{c}-0.057 * * \\
(0.024)\end{array}$ & $\begin{array}{l}-0.05^{*} \\
(0.027)\end{array}$ \\
\hline Log of initial income & & $\begin{array}{c}-0.67 * * * \\
(0.11)\end{array}$ & $\begin{array}{c}-0.67 * * * \\
(0.11)\end{array}$ & $\begin{array}{c}-0.65 * * * \\
(0.13)\end{array}$ & $\begin{array}{c}-0.66 * * * \\
(0.13)\end{array}$ \\
\hline Log of initial income squared & & $\begin{array}{c}0.033 * * * \\
(0.007)\end{array}$ & $\begin{array}{c}0.033 * * * \\
(0.007)\end{array}$ & $\begin{array}{c}0.032 * * * \\
(0.007)\end{array}$ & $\begin{array}{c}0.033^{* * *} * \\
(0.007)\end{array}$ \\
\hline Schooling & & $\begin{array}{c}0.002 * * * \\
(0.0005)\end{array}$ & $\begin{array}{c}0.002 * * * \\
(0.0005)\end{array}$ & $\begin{array}{c}0.003 * * * \\
(0.0007)\end{array}$ & $\begin{array}{c}0.003 * * * \\
(0.0008)\end{array}$ \\
\hline War & & & $\begin{array}{c}-0.03 \\
(0.026)\end{array}$ & $\begin{array}{c}-0.04 \\
(0.028)\end{array}$ & $\begin{array}{c}-0.04 \\
(0.028)\end{array}$ \\
\hline Financial depth & & & & $\begin{array}{r}-0.0007 \\
(0.014) \\
\end{array}$ & $\begin{array}{c}-0.0009 \\
(0.014) \\
\end{array}$ \\
\hline Black market premium & & & & $\begin{array}{c}0.001 \\
(0.01)\end{array}$ & $\begin{array}{l}0.001 \\
(0.01)\end{array}$ \\
\hline Fiscal surplus/GDP & & & & $\begin{array}{c}-0.0009 \\
(0.0018)\end{array}$ & $\begin{array}{c}-0.0008 \\
(0.0018)\end{array}$ \\
\hline Phones per capita & & & & & $\begin{array}{c}0.07 \\
(0.14)\end{array}$ \\
\hline Time period dummies? & Yes & Yes & Yes & Yes & Yes \\
\hline $\mathrm{R}^{2}($ Overall $)$ & 0.02 & 0.20 & 0.20 & 0.21 & 0.21 \\
\hline $\mathrm{N}$ & $26 ; 26 ; 26$ & $26 ; 26 ; 26$ & $26 ; 26 ; 26$ & $26 ; 26 ; 26$ & $26 ; 26 ; 26$ \\
\hline
\end{tabular}

Note: Standard deviations are in parentheses; $*$ significant at $10 \%, * *$ significant at $5 \%, * * *$ significant at $1 \%$ 
Table 6.

Endogenous Ethnic Fractionalization and Economic Growth

3SLS (Three stage least squares) estimates

(Dependent variable is growth of per capita GDP)

\begin{tabular}{|c|c|c|c|c|c|}
\hline & (1) & (2) & (3) & (4) & (5) \\
\hline $\begin{array}{l}\text { Endogenous ethnic } \\
\text { fractionalization }\end{array}$ & $\begin{array}{l}-0.25 * * * \\
(0.078)\end{array}$ & $\begin{array}{l}-0.14^{*} \\
(0.078)\end{array}$ & $\begin{array}{l}-0.13 * \\
(0.075)\end{array}$ & $\begin{array}{l}-0.14^{*} \\
(0.082)\end{array}$ & $\begin{array}{l}-0.15^{*} \\
(0.083)\end{array}$ \\
\hline Dummy for the CIS & & $\begin{array}{l}-0.036^{*} \\
(0.021)\end{array}$ & $\begin{array}{l}-0.031 \\
(0.022)\end{array}$ & $\begin{array}{l}-0.037 \\
(0.028)\end{array}$ & $\begin{array}{l}-0.031 \\
(0.03)\end{array}$ \\
\hline Log of initial income & & $\begin{array}{c}-0.61 * * * \\
(0.15)\end{array}$ & $\begin{array}{c}-0.6^{* * * *} \\
(0.14)\end{array}$ & $\begin{array}{c}-0.6^{* * * *} \\
(0.14)\end{array}$ & $\begin{array}{c}-0.61 * * * \\
(0.15)\end{array}$ \\
\hline Log of initial income squared & & $\begin{array}{l}0.031 * * * \\
(0.0085)\end{array}$ & $\begin{array}{l}0.03 * * * \\
(0.008)\end{array}$ & $\begin{array}{c}0.03 * * * \\
(0.008)\end{array}$ & $\begin{array}{c}0.03 * * * \\
(0.008)\end{array}$ \\
\hline Schooling & & $\begin{array}{c}0.0025 * * * \\
(0.0007)\end{array}$ & $\begin{array}{c}0.0026 * * * \\
(0.0007)\end{array}$ & $\begin{array}{c}0.0026 * * * \\
(0.0007)\end{array}$ & $\begin{array}{c}0.0024 * * * \\
(0.0009)\end{array}$ \\
\hline War & & & $\begin{array}{l}-0.062^{*} \\
(0.034)\end{array}$ & $\begin{array}{c}-0.065^{*} \\
(0.036)\end{array}$ & $\begin{array}{c}-0.064 * \\
(0.035)\end{array}$ \\
\hline Financial depth & & & & $\begin{array}{c}0.006 \\
(0.019)\end{array}$ & $\begin{array}{c}0.006 \\
(0.019) \\
\end{array}$ \\
\hline Black market premium & & & & $\begin{array}{l}0.001 \\
(0.01)\end{array}$ & $\begin{array}{l}0.001 \\
(0.01)\end{array}$ \\
\hline Fiscal surplus/GDP & & & & $\begin{array}{l}-0.0003 \\
(0.002)\end{array}$ & $\begin{array}{l}-0.0003 \\
(0.002)\end{array}$ \\
\hline Phones per capita & & & & & $\begin{array}{l}0.075 \\
(0.17)\end{array}$ \\
\hline Time period dummies? & Yes & Yes & Yes & Yes & Yes \\
\hline $\mathrm{R}^{2}($ Overall $)$ & 0.10 & 0.33 & 0.19 & 0.0 .22 & 0.24 \\
\hline $\mathrm{N}$ & $26 ; 26 ; 26$ & $26 ; 26 ; 26$ & $26 ; 26 ; 26$ & $26 ; 26 ; 26$ & $26 ; 26 ; 26$ \\
\hline
\end{tabular}

Note: Standard deviations are in parentheses; * significant at $10 \%, * *$ significant at $5 \%$,*** significant at $1 \%$. See text for details on the fractionalization equation. 
Table 7.

Endogenous Linguistic Fractionalization and Economic Growth

3SLS (Three stage least squares) estimates

(Dependent variable is growth of per capita GDP)

\begin{tabular}{|c|c|c|c|c|c|}
\hline & (1) & (2) & (3) & (4) & (5) \\
\hline $\begin{array}{l}\text { Endogenous linguistic } \\
\text { fractionalization }\end{array}$ & $\begin{array}{c}0.067 * * * \\
(0.033)\end{array}$ & $\begin{array}{l}-0.046 \\
(0.043) \\
\end{array}$ & $\begin{array}{l}-0.057 \\
(0.046) \\
\end{array}$ & $\begin{array}{c}-0.05 \\
(0.052) \\
\end{array}$ & $\begin{array}{l}-0.062 \\
(0.052) \\
\end{array}$ \\
\hline Dummy for the CIS & & $\begin{array}{c}-0.043 * * \\
(0.016)\end{array}$ & $\begin{array}{c}-0.037 * * \\
(0.018)\end{array}$ & $\begin{array}{l}-0.045^{*} \\
(0.024)\end{array}$ & $\begin{array}{l}-0.028 \\
(0.027)\end{array}$ \\
\hline Log of initial income & & $\begin{array}{c}-0.631 * * * \\
(0.13)\end{array}$ & $\begin{array}{c}-0.63 * * * \\
(0.13)\end{array}$ & $\begin{array}{c}-0.585^{* * * *} \\
(0.14)\end{array}$ & $\begin{array}{c}-0.607 * * * \\
(0.14)\end{array}$ \\
\hline $\begin{array}{l}\text { Log of initial income } \\
\text { squared }\end{array}$ & & $\begin{array}{c}0.033 * * * \\
(0.008)\end{array}$ & $\begin{array}{c}0.033 * * * \\
(0.008)\end{array}$ & $\begin{array}{c}0.03 * * * \\
(0.008)\end{array}$ & $\begin{array}{c}0.031 * * * \\
(0.008)\end{array}$ \\
\hline Schooling & & $\begin{array}{l}0.002 * * * \\
(0.0007)\end{array}$ & $\begin{array}{c}0.0023 * * * \\
(0.0007)\end{array}$ & $\begin{array}{l}0.002 * * \\
(0.0008)\end{array}$ & $\begin{array}{c}0.0014 \\
(0.0009)\end{array}$ \\
\hline War & & & $\begin{array}{l}-0.045 \\
(0.032)\end{array}$ & $\begin{array}{l}-0.056^{*} \\
(0.034)\end{array}$ & $\begin{array}{l}-0.062^{*} \\
(0.034)\end{array}$ \\
\hline Financial depth & & & & $\begin{array}{l}-0.0094 \\
(0.017) \\
\end{array}$ & $\begin{array}{l}-0.0091 \\
(0.017)\end{array}$ \\
\hline Black market premium & & & & $\begin{array}{l}0.001 \\
(0.01)\end{array}$ & $\begin{array}{l}0.001 \\
(0.01)\end{array}$ \\
\hline Fiscal surplus/GDP & & & & $\begin{array}{l}-0.0029 \\
(0.002)\end{array}$ & $\begin{array}{l}-0.0028 \\
(0.002)\end{array}$ \\
\hline Phones per capita & & & & & $\begin{array}{l}0.203 \\
(0.14) \\
\end{array}$ \\
\hline Time period dummies? & Yes & Yes & Yes & Yes & Yes \\
\hline $\mathrm{R}^{2}($ Overall $)$ & 0.12 & 0.22 & 0.23 & 0.22 & 0.19 \\
\hline $\mathrm{N}$ & $26 ; 26 ; 26$ & $26 ; 26 ; 26$ & $26 ; 26 ; 26$ & $26 ; 26 ; 26$ & $26 ; 26 ; 26$ \\
\hline
\end{tabular}

Note: Standard deviations are in parentheses; * significant at $10 \%, * *$ significant at $5 \%, * * *$ significant at $1 \%$. See text for details on the fractionalization equation. 
Table 8.

Endogenous Religious Fractionalization and Economic Growth

3SLS (Three stage least squares) estimates

(Dependent variable is growth of per capita GDP)

\begin{tabular}{|c|c|c|c|c|c|}
\hline & (1) & (2) & (3) & (4) & $(5)$ \\
\hline Endogenous Religion & $\begin{array}{c}-0.0156 \\
(0.04)\end{array}$ & $\begin{array}{l}0.107 * * \\
(0.042)\end{array}$ & $\begin{array}{l}0.096 * * \\
(0.047)\end{array}$ & $\begin{array}{c}0.079 \\
(0.048)\end{array}$ & $\begin{array}{l}0.074 \\
(0.05)\end{array}$ \\
\hline Dummy for the CIS & & $\begin{array}{c}-0.06 * * * \\
(0.017)\end{array}$ & $\begin{array}{c}-0.053^{* * * *} \\
(0.02)\end{array}$ & $\begin{array}{c}-0.059 * * \\
(0.028)\end{array}$ & $\begin{array}{l}-0.052 \\
(0.034)\end{array}$ \\
\hline Log of initial income & & $\begin{array}{c}-0.71 * * * \\
(0.13)\end{array}$ & $\begin{array}{c}-0.678 * * * \\
(0.13)\end{array}$ & $\begin{array}{c}-0.618 * * * \\
(0.15)\end{array}$ & $\begin{array}{c}-0.631 * * * \\
(0.15)\end{array}$ \\
\hline $\begin{array}{l}\text { Log of initial income } \\
\text { squared }\end{array}$ & & $\begin{array}{c}0.036^{* * * *} \\
(0.008)\end{array}$ & $\begin{array}{c}0.03 * * * \\
(0.008)\end{array}$ & $\begin{array}{l}0.03 * * * \\
(0.0085)\end{array}$ & $\begin{array}{c}0.031 * * * \\
(0.009)\end{array}$ \\
\hline Schooling & & $\begin{array}{c}0.0026 * * * \\
(0.0007)\end{array}$ & $\begin{array}{c}0.0031 * * * \\
(0.0007)\end{array}$ & $\begin{array}{r}0.0029 * * * \\
(0.00086)\end{array}$ & $\begin{array}{c}0.0028 * * * \\
(0.001)\end{array}$ \\
\hline War & & & $\begin{array}{l}-0.06^{*} \\
(0.03)\end{array}$ & $\begin{array}{l}-0.07 * * \\
(0.034)\end{array}$ & $\begin{array}{l}-0.07 * * \\
(0.034)\end{array}$ \\
\hline Financial depth & & & & $\begin{array}{l}-0.0094 \\
(0.016)\end{array}$ & $\begin{array}{l}-0.0094 \\
(0.016)\end{array}$ \\
\hline Black market premium & & & & $\begin{array}{l}0.001 \\
(0.01)\end{array}$ & $\begin{array}{l}0.001 \\
(0.01)\end{array}$ \\
\hline Fiscal surplus/GDP & & & & $\begin{array}{l}-0.0022 \\
(0.002)\end{array}$ & $\begin{array}{l}-0.002 \\
(0.002)\end{array}$ \\
\hline Phones per capita & & & & & $\begin{array}{l}0.068 \\
(0.18) \\
\end{array}$ \\
\hline Time period dummies? & Yes & Yes & Yes & Yes & Yes \\
\hline $\mathrm{R}^{2}$ (Overall) & 0.02 & 0.08 & 0.08 & 0.09 & 0.11 \\
\hline $\mathrm{N}$ & $26 ; 26 ; 26$ & $26 ; 26 ; 26$ & $26 ; 26 ; 26$ & $26 ; 26 ; 26$ & $26 ; 26 ; 26$ \\
\hline
\end{tabular}

Note: Standard deviations are in parentheses; * significant at $10 \%, * *$ significant at $5 \%, * * *$ significant at $1 \%$. See text for details on the fractionalization equation. 
APPENDIX A

Fractionalization indices: Ethnic, linguistic, and religious

Table A.1

The dynamics of ethnic fractionalization in transition economies, 1989-2002

(Larger numbers indicate greater heterogeneity)

\begin{tabular}{|l|l|l|l|}
\hline & $1989-93$ & $1994-98$ & $1999-2002$ \\
\hline Albania & & & \\
\hline Armenia & 0.0962 & 0.0776 & 0.1596 \\
\hline Azerbaijan & 0.1282 & 0.0778 & 0.0415 \\
\hline Belarus & 0.3078 & 0.2047 & 0.1766 \\
\hline Bulgaria & 0.3734 & 0.3538 & 0.3252 \\
\hline Croatia & 0.2548 & 0.2658 & 0.2821 \\
\hline Czech Republic & 0.3657 & 0.1848 & 0.1912 \\
\hline Estonia & 0.3216 & 0.3250 & 0.1791 \\
\hline Georgia & 0.5281 & 0.5062 & 0.4722 \\
\hline Hungary & 0.4852 & 0.4598 & 0.3019 \\
\hline Kazakhstan & 0.1838 & 0.1496 & 0.1425 \\
\hline Kyrgyz Republic & 0.6871 & 0.6659 & 0.6180 \\
\hline Latvia & 0.6577 & 0.5936 & 0.5407 \\
\hline Lithuania & 0.6096 & 0.5931 & 0.5766 \\
\hline Macedonia & 0.3524 & 0.3267 & 0.2946 \\
\hline Moldova & 0.5303 & 0.5012 & 0.5074 \\
\hline Mongolia & 0.5441 & 0.5289 & 0.5378 \\
\hline Poland & 0.3568 & 0.3354 & 0.3140 \\
\hline Romania & 0.0257 & 0.0471 & 0.0139 \\
\hline Russian Federation & 0.1940 & 0.3069 & 0.1939 \\
\hline Slovak Republic & 0.3261 & 0.3033 & 0.3493 \\
\hline Slovenia & 0.2535 & 0.2539 & 0.2540 \\
\hline Tajikistan & 0.2114 & 0.1657 & 0.2869 \\
\hline Turkmenistan & 0.5465 & 0.4683 & 0.5107 \\
\hline Ukraine & 0.4555 & 0.3891 & 0.1690 \\
\hline Uzbekistan & 0.4218 & 0.4737 & 0.3636 \\
\hline & 0.4708 & 0.4125 & 0.3802 \\
\hline Average & & & \\
\hline Source: Author & 0.345 & \\
\hline & 0.3726 & & \\
\hline & & & \\
\hline & & & \\
\hline & & & \\
\hline & & & \\
\hline & & & \\
\hline & & & \\
\hline
\end{tabular}

Source: Authors' calculations.

Note: Averages based on same number of groups per country over time(i.e., "restricted") 
Table A.2

The dynamics of linguistic fractionalization in transition economies, 1989-2002 (Larger numbers indicate greater heterogeneity)

\begin{tabular}{|l|l|l|l|}
\hline & $1989-93$ & $1994-98$ & $1999-2002$ \\
& & & \\
\hline Albania & 0.0398 & 0.0401 & 0.0399 \\
\hline Armenia & 0.1273 & 0.1250 & 0.1291 \\
\hline Azerbaijan & 0.3129 & 0.2043 & 0.2054 \\
\hline Belarus & 0.4659 & 0.4671 & 0.4665 \\
\hline Bulgaria & 0.2622 & 0.2985 & 0.3030 \\
\hline Croatia & 0.0763 & 0.0779 & 0.0763 \\
\hline Czech Republic & 0.3207 & 0.3232 & 0.3233 \\
\hline Estonia & 0.4931 & 0.4959 & 0.4923 \\
\hline Georgia & 0.4707 & 0.4701 & 0.4749 \\
\hline Hungary & 0.1348 & 0.0294 & 0.0297 \\
\hline Kazakhstan & 0.6178 & 0.6598 & 0.6601 \\
\hline Kyrgyz Republic & 0.6338 & 0.5888 & 0.5874 \\
\hline Latvia & 0.5491 & 0.5748 & 0.5690 \\
\hline Lithuania & 0.3383 & 0.3212 & 0.3212 \\
\hline Macedonia & 0.4703 & 0.5024 & 0.5019 \\
\hline Moldova & 0.5546 & 0.5526 & 0.5529 \\
\hline Mongolia & 0.5990 & 0.6456 & 0.6023 \\
\hline Poland & 0.0471 & 0.0468 & 0.0468 \\
\hline Romania & 0.2000 & 0.1722 & 0.1723 \\
\hline Russia & 0.2486 & 0.2488 & 0.2485 \\
\hline Slovakia & 0.2551 & 0.2537 & 0.2551 \\
\hline Slovenia & 0.1681 & 0.2171 & 0.2198 \\
\hline Tajikistan & 0.5486 & 0.5467 & 0.5473 \\
\hline Turkmenistan & 0.4541 & 0.3940 & 0.3938 \\
\hline Ukraine & 0.4741 & 0.4737 & 0.4741 \\
\hline Uzbekistan & 0.4699 & 0.4691 & 0.4120 \\
\hline & 0.3589 & 0.3538 & 0.3501 \\
\hline Average & & & \\
\hline Source: Auta & & \\
\hline & & & \\
\hline & & & \\
\hline & & & \\
\hline & & & \\
\hline & & & \\
\hline & & & \\
\hline & & & \\
\hline
\end{tabular}

Source: Authors' calculations.

Note: Averages based on same number of groups per country over time (i.e., "restricted") 
Table A.3

The dynamics of religious fractionalization in transition economies, 1989-2002 (Larger numbers indicate greater heterogeneity)

\begin{tabular}{|c|c|c|c|}
\hline & 1989-93 & 1994-98 & 1999-2002 \\
\hline Albania & 0.5193 & 0.4713 & 0.6947 \\
\hline Armenia & 0.3200 & 0.4580 & 0.4582 \\
\hline Azerbaijan & 0.1233 & 0.1244 & 0.1233 \\
\hline Belarus & 0.2713 & 0.6118 & 0.6119 \\
\hline Bulgaria & 0.2232 & 0.5956 & 0.4462 \\
\hline Croatia & 0.3911 & 0.4445 & 0.2133 \\
\hline Czech Republic & 0.6594 & 0.6592 & 0.6591 \\
\hline Estonia & 0.4979 & 0.4962 & 0.5048 \\
\hline Georgia & 0.5451 & 0.5858 & 0.6553 \\
\hline Hungary & 0.5194 & 0.5238 & 0.5559 \\
\hline Kazakhstan & 0.5896 & 0.5898 & 0.5898 \\
\hline Kyrgyz Republic & 0.4477 & 0.4477 & 0.3968 \\
\hline Latvia & 0.5595 & 0.5555 & 0.5557 \\
\hline Lithuania & 0.4141 & 0.4141 & 0.4149 \\
\hline Macedonia & 0.5622 & 0.5913 & 0.5555 \\
\hline Moldova & 0.4582 & 0.5605 & 0.5600 \\
\hline Mongolia & 0.0768 & 0.0792 & 0.0786 \\
\hline Poland & 0.1015 & 0.1687 & 0.1689 \\
\hline Romania & 0.2374 & 0.2374 & 0.2368 \\
\hline Russia & 0.4392 & 0.4404 & 0.4087 \\
\hline Slovakia & 0.5665 & 0.5675 & 0.5655 \\
\hline Slovenia & 0.1128 & 0.2861 & 0.2824 \\
\hline Tajikstan & 0.3200 & 0.3350 & 0.3528 \\
\hline Turkmenistan & 0.2637 & 0.2313 & 0.2312 \\
\hline Ukraine & 0.6086 & 0.6076 & 0.5610 \\
\hline Uzbekistan & 0.2255 & 0.0221 & 0.0200 \\
\hline Average & 0.3862 & 0.4345 & 0.4183 \\
\hline
\end{tabular}


APPENDIX B: Description of the data

\begin{tabular}{|c|c|}
\hline Variable & Description, source \\
\hline Growth of per capita GDP & Growth rate of PPP-adjusted GDP. WEO (WDI), UNDP, CIA, PWT \\
\hline Time Dummies & Dummy variable for 1989-1993, 1994-1998, 1999-2003 \\
\hline CIS & Dummy for CIS countries \\
\hline Log of initial income & Log of real per capita GDP calculated at the beginning of each period \\
\hline War & $\begin{array}{l}\text { Dummy variable for the presence of war: } 1 \text { if there is a war in a } \\
\text { country in the period, } 0 \text { otherwise. }\end{array}$ \\
\hline Financial depth & $\begin{array}{l}\text { Financial depth: log of ratio of broad money to GDP, period average. } \\
\text { EBRD Transition Reports, IMF for Mongolia }\end{array}$ \\
\hline Black market premium & Black market premium, DDGT (97) \\
\hline Fiscal surplus/GDP & $\begin{array}{l}\text { Fiscal surplus/GDP: period average of ratio of general government } \\
\text { surplus (deficit) to GDP, period average EBRD Transition Reports, } \\
\text { IMF (International Financial Statistics) for Mongolia }\end{array}$ \\
\hline Phones per capita & Telephones per capita, period average UN Statistical Yearbook \\
\hline Ethnic (language, religion) & $\begin{array}{l}\text { Index of ethnic (linguistic, religious) fractionalization index for each } \\
\text { period, see data in Appendix I }\end{array}$ \\
\hline Bank & Bank Sector Reform index, period average, EBRD Transition Reports \\
\hline Civil liberties & Index of civil liberties, period average, Freedom House. \\
\hline Competition & Competition Policy index, period average, EBRD Transition Reports \\
\hline Democracy & Democracy-autocracy index, period average, Polity IV \\
\hline Enterprise & Enterprise reform index, period average, EBRD Transition Reports \\
\hline Illiteracy & $\begin{array}{l}\text { Adult illiteracy rate, data for } 1990,1995,2000 \text {, Human Development } \\
\text { Reports, UNDP }\end{array}$ \\
\hline Infrastructure & Index on infrastructure reform, EBRD Transition Reports \\
\hline Log of infant mortality & $\begin{array}{l}\text { Logarithm of number of deaths of infants under one year of age per } \\
\text { one thousand live births, period average, Transmonee database }\end{array}$ \\
\hline Log GDP per capita & $\begin{array}{l}\text { Logarithm of ppp-adjusted GDP per capita, period average, WEO } \\
\text { (WDI), UNDP, CIA, PWT }\end{array}$ \\
\hline Latitude & The value of the latitude of the country, CIA 2000 \\
\hline Log of population & $\begin{array}{l}\text { Logarithm of population of the country in 1989, in thousands, } \\
\text { Transmonee database, CIA WFB 1992-1993 for Mongolia }\end{array}$ \\
\hline Large-scale privatization & $\begin{array}{l}\text { Large-scale privatization index, period average, EBRD Transition } \\
\text { Reports }\end{array}$ \\
\hline Leg sys civil law & Dummy for legal system: civil law \\
\hline Political rights & Index of political rights, period average, Freedom House. \\
\hline Small-scale privatization & Small-scale privatization index, EBRD Transition Reports \\
\hline Price liberalization & Price liberalization index, period average, EBRD Transition Reports \\
\hline Trade and foreign exchange & $\begin{array}{l}\text { Trade and foreign exchange liberalization index, period average, } \\
\text { EBRD Transition Reports }\end{array}$ \\
\hline Corruption & $\begin{array}{l}\text { Corruption index for } 2003 \text {, Transparency International, scale: } 0 \text { - } \\
\text { highly corrupt, } 10 \text { - highly transparent. }\end{array}$ \\
\hline
\end{tabular}




\section{APPENDIX C: Fractionalization, Polarization and Other Banes}

This Appendix reports how the results presented above change if we measure diversity as polarization (instead of fractionalization). The family of polarization measures proposed by Esteban and Ray $(1994,1999)$ has been implemented in various ways. The approach used by Alesina et al. (2003) is:

$$
\text { ADEKW Polarization }=K \sum_{i=1}^{n} \sum_{j=1}^{n} s_{i}^{1+\alpha} s_{j}\left|y_{i}-y_{j}\right|
$$

where $\mathrm{K}$ is a scaling factor and $\alpha$ is a constant between 0 and 1.6. Note that this formulation requires a measure of distance between groups (the last term in the right-hand side), which can be thought, for instance, as differences in median incomes. However, and partly because of severe data constraints, distance is often assumed constant and equal to 1. Following Alesina et al. (2003) we recalculate our measures of ethnic, linguistic and religious fractionalization, using $\alpha=0.8$ and $\alpha=1.6$ and repeat all the previous regressions with ethnicity, language and religion polarization indices instead. Here we report on our exercise of replicating the results in this paper using the polarization concept instead. As can be seen in the two Tables below, the results are qualitatively the same as those reported in the main body of the paper (namely, robust only for endogenous ethnic fractionalization). 
Table C.1

Exogenous Polarization and Economic Growth

SUR estimates

(Dependent variable is growth of per capita GDP)

\begin{tabular}{|l|c|c|c|c|c|}
\hline & $(1)$ & $(2)$ & $(3)$ & $(4)$ & $(5)$ \\
\hline & & & & & $-0.23^{*}$ \\
Ethnic polarization $(\alpha=0.8)$ & $(0.1)$ & $(0.11)$ & $(0.12)$ & $(0.13)$ & $(0.13)$ \\
\hline & $-0.83^{* * *}$ & $-0.41^{*}$ & $-0.44^{*}$ & $-0.5^{*}$ & $-0.55^{* *}$ \\
Ethnic polarization $(\alpha=1.6)$ & $(0.2)$ & $(0.22)$ & $(0.23)$ & $(0.26)$ & $(0.26)$ \\
\hline & $-0.28^{* * *}$ & -0.05 & -0.1 & -0.12 & -0.13 \\
Linguistic polarization $(\alpha=0.8)$ & $(0.08)$ & $(0.09)$ & $(0.1)$ & $(0.12)$ & $(0.12)$ \\
\hline & $-0.59 * * *$ & -0.07 & -0.14 & -0.17 & -0.22 \\
Linguistic polarization $(\alpha=1.6)$ & $(0.15)$ & $(0.2)$ & $(0.21)$ & $(0.25)$ & $(0.25)$ \\
\hline & -0.04 & $0.28^{* * *}$ & $0.27 * * *$ & $0.26 * *$ & $0.25^{* *}$ \\
Religious polarization $(\alpha=0.8)$ & $(0.1)$ & $(0.08)$ & $(0.1)$ & $(0.1)$ & $(0.11)$ \\
\hline & $-0.59^{* * *}$ & -0.07 & -0.14 & -0.17 & -0.22 \\
Religious polarization $(\alpha=1.6)$ & $(0.15)$ & $(0.2)$ & $(0.21)$ & $(0.25)$ & $(0.26)$ \\
\hline Time period dummies? & Yes & Yes & Yes & Yes & Yes \\
\hline $\mathrm{N}$ & $26 ; 26 ; 26$ & $26 ; 26 ; 26$ & $26 ; 26 ; 26$ & $26 ; 26 ; 26$ & $26 ; 26 ; 26$ \\
\hline
\end{tabular}

Note: Only coefficients for polarization indices are reported. Standard deviations are in parentheses; * significant at $10 \%$, ** significant at $5 \%, * * *$ significant at $1 \%$. Columns follow the specifications of the tables 3 through 8 . 
Table C. 2

Endogenous Polarization and Economic Growth

3SLS estimates

(Dependent variable is growth of per capita GDP)

\begin{tabular}{|c|c|c|c|c|c|}
\hline & (1) & (2) & (3) & (4) & (5) \\
\hline Ethnic polarization $(\alpha=0.8)$ & $\begin{array}{c}-0.69 * * * \\
(0.21)\end{array}$ & $\begin{array}{l}-0.39 * \\
(0.21)\end{array}$ & $\begin{array}{c}-0.38^{*} \\
(0.2)\end{array}$ & $\begin{array}{l}-0.39^{*} \\
(0.22)\end{array}$ & $\begin{array}{l}-0.45^{*} \\
(0.22)\end{array}$ \\
\hline Ethnic polarization $(\alpha=1.6)$ & $\begin{array}{c}-1.8 * * * \\
(0.47) \\
\end{array}$ & $\begin{array}{c}-1.25 * * \\
(0.5) \\
\end{array}$ & $\begin{array}{c}-1.21 * * \\
(0.48) \\
\end{array}$ & $\begin{array}{l}-1.2 * * \\
(0.53)\end{array}$ & $\begin{array}{c}-1.48 * * \\
(0.57)\end{array}$ \\
\hline Linguistic polarization $(\alpha=0.8)$ & $\begin{array}{c}-0.53 * * * \\
(0.15)\end{array}$ & $\begin{array}{c}-0.28 \\
(0.18)\end{array}$ & $\begin{array}{l}-0.32^{*} \\
(0.17)\end{array}$ & $\begin{array}{c}-0.36^{*} \\
(0.2)\end{array}$ & $\begin{array}{c}-0.41^{*} \\
(0.21\end{array}$ \\
\hline Linguistic polarization $(\alpha=1.6)$ & $\begin{array}{c}-1.27 * * * \\
(0.32)\end{array}$ & $\begin{array}{l}-0.68 \\
(0.41) \\
\end{array}$ & $\begin{array}{c}-0.83 * * \\
(0.41)\end{array}$ & $\begin{array}{c}-0.8 \\
(0.48)\end{array}$ & $\begin{array}{l}1.01 * \\
(0.52)\end{array}$ \\
\hline Religious polarization $(\alpha=0.8)$ & $\begin{array}{l}0.017 \\
(0.26)\end{array}$ & $\begin{array}{c}0.34 \\
(0.21)\end{array}$ & $\begin{array}{l}0.35^{*} \\
(0.21)\end{array}$ & $\begin{array}{c}0.4^{*} \\
(0.22)\end{array}$ & $\begin{array}{l}0.46^{*} \\
(0.24)\end{array}$ \\
\hline Religious polarization $(\alpha=1.6)$ & $\begin{array}{l}-0.48 \\
(0.63)\end{array}$ & $\begin{array}{c}0.48 \\
(0.49)\end{array}$ & $\begin{array}{c}0.53 \\
(0.48)\end{array}$ & $\begin{array}{c}0.67 \\
(0.52)\end{array}$ & $\begin{array}{c}0.76 \\
(0.57)\end{array}$ \\
\hline Time period dummies? & Yes & Yes & Yes & Yes & Yes \\
\hline $\mathrm{N}$ & $26 ; 26 ; 26$ & $26 ; 26 ; 26$ & $26 ; 26 ; 26$ & $26 ; 26 ; 26$ & $26 ; 26 ; 26$ \\
\hline
\end{tabular}

Note: Only coefficients for polarization indices are reported. Standard deviations are in parentheses; * significant at $10 \%, * *$ significant at $5 \%, * * *$ significant at $1 \%$. Columns follow the specifications of the tables 3 through 8 . 